\title{
An experimental study of native speaker perceptions of non-native request modification in e-mails in English
}

\author{
BERNA HENDRIKS
}

Abstract

An area of intercultural pragmatics (ILP) that has been investigated extensively is the ability of learners to understand and use indirect and polite language in performing speech acts. ILP studies that have investigated learners' ability to modify speech acts have shown that learners tend to use fewer and less varied modifiers than native speakers (Faerch and Kasper 1989; Hendriks 2002). To date, however, few studies have investigated the effect of non-native modification of speech acts. Evidence from research on the comprehensibility of EFL language has indicated that grammatical errors and / or non-native pronunciation can obstruct comprehension (Lindemann 2003) and that non-native speakers may be evaluated negatively with regard to their personality (Bresnahan et al. 2002; Nejjari et al. forthcoming).

This study investigated the effect of the (under) use of syntactic and lexical modifiers in English e-mail requests written by Dutch learners. In an online web-survey, native speakers of English were asked to evaluate the comprehensibility of the e-mail requests and personality dimensions of the sender of the e-mail. Findings indicate that underuse of request modification in e-mails had a negative effect on participants' evaluation of the personality of the sender of the e-mail.

\section{Introduction}

As a result of globalization, organizations increasingly need to communicate in a foreign language with customers and organizations in other countries. This applies not only to large multinationals with business units in local target markets, but also to domestic organizations conducting business across national borders. Organizations have (at least) two choices with regard to the language of communication in their contacts 
with foreign business partners. Communication can either take place in the mother tongue of the foreign business partner, or in a lingua franca (often English) that is not the mother tongue for either of the parties involved. Either way, at least one party is required to communicate in a language that is not the mother tongue.

Mainstream second language acquisition research (SLA) has convincingly demonstrated that non-native speakers of a language differ from native speakers at the level of grammatical competence (pronunciation, lexis, syntax, etc.) but also, and perhaps more importantly, with regard to business communication, at the level of pragmatic competence (e.g., use of pragmalinguistic and sociopragmatic conventions). Studies of L2 comprehension have indicated that grammatical errors can lead to misunderstanding and negative stereotyping of language learners by native speakers (Delamere 1996; Derwing et al. 2002) and that non-native pronunciation can lead to reduced intelligibility of L2 speakers and negative personality evaluations (DeShields et al. 1997; Fayer and Krasinski 1987; Lindemann 2002, 2003; Tsalikis et al. 1991).

In the area of interlanguage pragmatics, research has convincingly demonstrated that non-native speakers tend to differ from native speakers at the level of pragmatic competence. Studies analyzing L2 speech act production, for example, have found that L2 speakers differ from native speakers in that they use fewer and less elaborate politeness strategies in the form of speech act modification (e.g. Blum-Kulka et al. 1989b; Gass and Neu 1996; Hendriks 2002; Maier 1992; Trosborg 1995). To date, however, few studies have been directed at investigating the effect of what might be called 'pragmatically accented' - non-native speech act behavior on native speaker perceptions (but see Biesenbach-Lucas 2005; Hartford and Bardovi-Harlig 1996).

In an earlier study of request production by Dutch learners of English (Hendriks 2002), it was found that Dutch (advanced) learners tended to use less modification in requests, and also less varied request modifiers than native speakers of English. The purpose of the present study was therefore to investigate whether variations in request modification in e-mail messages affect native speaker evaluations of Dutch non-native writers.

\section{Background}

\subsection{English in business communication in the Netherlands}

In the Netherlands, as in many other European countries, the dominant foreign language in business (as in most other domains) is English (Ger- 
ritsen and Nickerson 2004; Seidlhofer et al. 2006). English is widely used in different types of (business) genres such as annual reports (De Groot 2006), commercials (Gerritsen et al. 2000), print advertising (Gerritsen 1995; Gerritsen et al. 2007) and recruitment advertising (Korzilius et al. 2006; Van Meurs et al. 2006b). What is more, some Dutch-based multinationals such as Philips and Shell have made English their official corporate language.

Despite the fact that English is pervasively used in all layers of Dutch society, research has indicated that English is not always completely understood and / or appreciated (Gerritsen et al. 2000; Gerritsen et al. 2007; Van Meurs et al. 2006a). A recent study revealed, for example, that Dutch non-native speakers seem to overrate their English language skills (Van Onna and Jansen 2006). Also, research investigating the use of English at Dutch-based multinational companies indicates that employees experience problems communicating in English (Hemmes 1994; Nickerson 2000). Finally, studies investigating pragmatic competence have shown that even highly proficient Dutch learners may not be fully pragmatically proficient in English (Burrough-Boenisch 2005; Hendriks 2002, 2008; Planken 2005).

\subsection{Requests in Interlanguage Pragmatics}

Research in interlanguage pragmatics (ILP) has predominantly been concerned with documenting learners' use of pragmatic competence and, to a lesser extent, learners' development of pragmatic competence (for review, see Barron 2003; Jung 2002). An area of interlanguage pragmatics that has been investigated extensively is the ability of learners to understand and use indirect and polite language in performing speech acts, and requests in particular (Blum-Kulka et al. 1989b; Hendriks 2008; Trosborg 1995).

Most ILP request studies are based on the CCSARP (Cross-Cultural Study of Speech Act Realization Patterns) framework (Blum-Kulka et al. 1989a), which typically segments request utterances into a head act, which can be regarded as the 'core' of the request (underlined in (1)) and the remainder of the request utterance, which usually includes a variety of external modifiers. The head act, which includes the request strategy, is the minimal unit by which a request is performed.

(1) John, could I ask you a favor? Do you think you could go the presentation tomorrow? I really can't find the time to do it myself. I promise I'll take care of the next presentation. 
Table 1. Classification of request strategies (based on Hendriks 2002)

\begin{tabular}{ll}
\hline request strategy & example \\
\hline 1. imperative & Clean up that mess. \\
2. performative verb & I ask you to clean up that mess. \\
3. obligation statement & You must clean up that mess. \\
4. statement of want or wish & I want you to clean up that mess. \\
5. suggestion & Why don't you clean up that mess? \\
6. query preparatory & Will you clean up that mess? \\
$\begin{array}{l}\text { a. non-obviousness } \\
\text { b. willingness } \\
\text { c. ability }\end{array}$ & Are you willing to clean up that mess? \\
7. hint & Can you clean up that mess? \\
\hline
\end{tabular}

For the analysis of the request strategy, the request per se, the majority of ILP studies use a taxonomy based on the original CCSARP framework, in which strategies are ordered on a scale of decreasing directness, ranging from direct strategies (e.g. imperatives and want statements) to nonconventionally indirect strategies, such as hints (see Table 1).

ILP request studies have shown that both native speakers and nonnative speakers generally formulate requests with conventionally indirect strategies such as query preparatory strategies in which a speaker/writer questions the ability or willingness of the hearer/receiver to comply with a request (e.g., "Can you help me?"). Higher-intermediate and advanced learners, in particular, seem capable of approaching target language 'norms' with respect to varying the directness level of request strategies relative to contextual and situational requirements. Still, even highly proficient foreign language learners may find it difficult to use appropriate request modification in a target language (Hendriks 2002; House and Kasper 1987; Trosborg 1995).

In addition to varying the directness level of a request with request strategies, speakers can use request modification to mitigate the illocutionary force of a request. Speakers can use internal and external request modification (Blum-Kulka et al. 1989b). Internal request modification occurs when the head act of the request is modified and can be realized with syntactic means or with lexical/phrasal means. Examples of syntactic means are past tense modals, negation or tag questions, see (3a) and (3b).

(3) a. Could you help me? (vs. unmodified 'Can you')

b. You couldn't help me, could you? (negation + tag question)

In addition, speakers can use a variety of lexical/phrasal means for internal request modification, such as politeness marker please, downtoners 
(e.g. 'maybe'), understaters (e.g. 'just') and subjectivizers (e.g. 'I was hoping'), see (4a) and (4b).

(4) a. Can you help me, please?

b. I was hoping you could maybe just help me.

External modifiers (also called supportive moves) occur outside the head act of the request and generally include reasons, justifications, rewards etc. for the request, see (5a) and (5b).

(5) a. Could you hand in the report tomorrow? I really need it tomorrow.

b. Can you give me a hand with these boxes? I'll help you with yours this afternoon.

Oral production studies have consistently found that learners tend to use less (internal) request modification and also different types of request modifiers compared to native speakers and that even advanced learners rarely seem to approach target language norms in these respects (Barron 2003; Hendriks 2002; House and Kasper 1987; Le Pair 2005; Van der Wijst 1996; Woodfield 2008).

Similar findings have been reported (e.g. Biesenbach-Lucas 2007; Chang and Hsu 1998; Hartford and Bardovi-Harlig 1996) for written, student-to-professor e-mail communication, where native English students use more varied linguistic means (lexical and syntactic) to convey politeness in their e-mails than non-native students, who used fewer lexical and syntactic modifiers and a more restricted range of modifiers. Still, the question remains as to what extent this underuse of modification will actually result in pragmatic failure (Thomas 1983).

\subsection{Situational variation in requesting behavior}

In addition to learning the linguistic means available in the target language for formulating face-threatening acts (FTAs), such as requests, non-native speakers of a language also need to learn how to vary the level of politeness of FTAs relative to contextual and situational variation. The degree of politeness required in formulating FTAs is primarily determined by three factors, (relative) power distance and social distance between speaker and hearer, and relative imposition of an FTA in a particular culture (Brown and Levinson, 1987). Just how these factors determine the amount of face-redress for a particular FTA is subject to cultural variation. A range of studies has demonstrated that power distance, in particular, seems to be the most stable attribute of role relations in determining linguistic variation, with most studies generally reporting 
increasing levels of politeness with an increase of relative power of the hearer (e.g., Blum-Kulka et al., 1985; Spencer-Oatey, 1997; Trosborg 1987). In a previous study investigating requests produced by Dutch learners of English, variations in requesting behavior were found to be most notably attributable to shifts in the authority relationship between interlocutors (Hendriks 2002). As research in culture-related values has identified power distance as a dimension on which cross-cultural variation can be found to occur (Hofstede 2001; Schwartz, 1994), adjusting the level of politeness to variations in power distance may be a potentially difficult area for non-native speakers of a language.

Assessments of power distance, social distance and imposition vary cross-culturally, but are also highly context-dependent. Blum-Kulka and House (1989) demonstrated that even for request situations where the role-relationship between speaker and hearer in terms of power distance and social distance was relatively clear, respondents had different assessments of specific contextual features such as the right of the speaker to make the request, the obligation of the hearer to comply with the request and the likelihood of compliance with the request. Similar findings with respect to the effect of context-specific features have been reported for other speech acts, such as apologies (Bergman and Kasper 1993; Olshtain 1989) or complaints (Olshtain and Weinbach 1993). These contextspecific dimensions have also been shown to be important determinants of appropriate politeness levels for successful speech act performance (Blum-Kulka and House 1989; Hendriks 2002).

\subsection{Sender evaluation}

Research investigating native-native communication has indicated that the use of speech act modification in oral messages can affect recipients' judgments of personal attributes of the sender of a message (Blankenship and Holtgraves 2005; Hosman and Siltanen 2006) and that even in e-mail communication, which lacks the visual and auditory cues available in face-to-face interaction, recipients tend to form judgments about senders (Byron and Baldridge 2007; Sherman 2003).

Research in native-non-native communication suggests that nonnative speakers of a language may be evaluated negatively in terms of personality on the basis of their foreign accent in the target language (DeShields et al. 1997; Fayer and Krasinski 1987; Nejjari et al. forthcoming; Tsalikis et al. 1991), and that grammatical errors may have a detrimental effect on recipients' evaluations (Delamere 1996; Derwing et al. 2002).

Given the abundance of production studies that have documented differences between native speakers and non-native speakers in the way they 
modify speech acts, it is surprising that few studies to date have been directed at exploring the effect of non-native speech modification on native speakers. Kasper and Schmidt (1996), in mapping out a research agenda for interlanguage pragmatics, indicate explicitly that there is a need for perception studies that investigate which aspects of non-native pragmatic behavior might result in pragmatic failure. They argue that "... simply identifying differences [between NNS and NS] does not inform us which of those differences may matter in interaction. Some differences between NS norms and L2 performance may result in negative stereotyping by NS message recipients, whereas others may be heard as somewhat different but perfectly appropriate alternatives" (1996: 56).

So far, however, perception studies with an ILP focus have been scarce and those that have looked at how modification might affect communication were based on a relatively small number of messages sent to the researchers themselves (Biesenbach-Lucas 2007; Hartford and BardoviHarlig 1996). None of these studies have, however, looked at the effect of request modification in a systematic way.

The aim of the present study was to determine the extent to which the (under)use of internal request modification in English e-mail requests written by Dutch non-native speakers affected speaker evaluation by native speakers of English. More specifically, two experimental studies, referred to in this paper, were carried out to investigate the effect of request modification in non-native e-mails written by Dutch non-native speakers of English. In the first study, we varied the amount of request modification in the request. In the second study, we varied different types of request modification in the request. For both studies, we investigated native speakers' reactions to variations in request modification in the e-mail messages. As previous research has pointed to power distance as an important determinant of politeness and a potentially difficult area for foreign language learners, this factor was systematically varied in both studies.

\section{Study I}

The aim of the first study was to examine the effect of variations in amount of request modification for one type of syntactic modification: past tense modal 'could' in combination with a conventionally indirect strategy, i.e., the "ability strategy" ('Can you help me'). Past tense modals function as mitigating devices in that they add an element of conditionality to a request, which offers the addressee of a request an option to refrain from complying. Past tense modals reduce the (negative) face 
threat a request might pose for an addressee and can thus be said to enhance the politeness value of a request (Brown and Levinson 1987; Leech 1983). This study examined whether inclusion of past tense modals in e-mail requests affected recipients' evaluations of senders. In addition, the study examined to what extent different power distance situations required a different level of request modification. As power distance has been found to be an important determinant of politeness, the study examined whether modification interacted with power distance in affecting sender evaluation.

\subsection{Method study I}

3.1.1. Participants. Participants were 57 male and 53 female participants. All participants were native speakers of English. The majority of participants were evenly spread among four age categories ranging from 21 to 60; all were highly educated.

3.1.2. Material. Four different work-related request scripts were developed which described an e-mail exchange between a Dutch non-native speaker of English and a native speaker of English. The scripts differed with respect to the role constellation between sender and receiver of the e-mail. In two of the four scripts (A and B), the receiver of the e-mail request was in a position of authority vis-à-vis the sender of the e-mail (high power distance). In the other two scripts (C and D), sender and receiver were more or less status equals (low power distance).

Next, a group of Dutch students of English were asked to write e-mails for each of the four scripts, one of which was selected to serve as stimulus for each script. In all e-mails, the requests were realized by means of a conventionally indirect request strategy: an ability strategy formulated with modal verb 'can'. We then created a syntactically modified version of all four e-mails by including past tense modal 'could' in the request strategy, which resulted in eight e-mails in total. The scripts and e-mails are included in appendix A.

3.1.3. Design and Procedure. The study used a 2 (power distance) $\times 2$ (modification) factorial design. There were two levels of power distance (high vs. low) and two levels of modification (- modification vs. + modification) resulting in four different distance-modification combinations; for each of these combinations there were two scripts. Each participant saw two of the four distance-modification combinations; one e-mail in a high power distance situation and one e-mail in a low power distance sit- 
Table 2. Overview of distribution e-mails and modifiers in questionnaires in study I

\begin{tabular}{lllllll}
\hline Version questionnaire & PD & modifier & e-mail 1 & PD & modifier & e-mail 2 \\
\hline Questionnaire 1 & - & + & C & + & - & A \\
Questionnaire 2 & + & + & A & - & - & C \\
Questionnaire 3 & + & - & A & - & + & D \\
Questionnaire 4 & - & - & D & + & + & A \\
Questionnaire 5 & + & - & B & - & + & C \\
Questionnaire 6 & - & - & C & + & + & B \\
Questionnaire 7 & - & + & D & + & - & B \\
Questionnaire 8 & + & + & B & - & - & D \\
\hline
\end{tabular}

uation. One of the two e-mails was formulated without internal modification, whereas the other e-mail was formulated with internal modification. Power distance, modification and scripts were systematically varied to control for order effects, which resulted in eight different versions of the questionnaire (Table 2).

Online questionnaires were constructed and potential participants were invited to take part in the experiment through messages posted on a variety of Internet forums. Participants were randomly assigned to one of the eight versions of the questionnaire in approximately equal numbers.

3.1.4. Instrumentation. The questionnaire started with a short instruction followed by a description of the situation and the first of two e-mails. After reading each e-mail, participants were asked to answer 7-point Likert scale questions (ranging from $1=$ totally disagree to $7=$ totally agree) about the personality of the sender and the comprehensibility of the e-mail and the reasonableness of the request (an example of the questionnaire is included in appendix B). For the present study, internal consistency of scales was calculated in terms of Cronbach's $\alpha$. Qualifications of Cronbach's $\alpha$ were determined using the criteria in Nunnally and Bernstein (1994). Composite means were calculated if the reliability of scales was found to be adequate or above $(\alpha>.70)$.

3.1.4.1. Personality of sender. Personality of the sender was measured because language attitudinal research has demonstrated that non-native language use may be reflected in negative evaluations of the non-native speaker as a person (rather than as a learner of the language) (e.g. Derwing et al. 2002; Thomas 1983). Participants' evaluation of the personality of the sender of the e-mail was measured on the basis of nine questions relating to three personality dimensions: competence (' reliable', 'competent', 'intelligent'), power ('controlling', 'authoritative', 'dominant') and 
agreeableness ('sympathetic', 'tactful', 'considerate'). The first two constructs, competence and power, were based on a validated questionnaire used in a large-scale accent attitudinal survey (Bayard et al. 2001). For both constructs personality traits with factor loadings $>.7$ were selected. For the third construct, agreeableness, we selected three prototypical adjectives from the Big Five taxonomy (e.g. Harvey et al. 1995). Internal consistency of the scales in the present study was good for competence $(\alpha=.89)$ and agreeableness $(\alpha=.87)$, and adequate for power $(\alpha=.74)$. Composite means were calculated for all three dimensions.

\subsubsection{Comprehensibility. Comprehensibility of the e-mail was mea-} sured on the basis of research into persuasiveness of messages (Hoeken 1995), which has pointed to comprehensibility as a prerequisite for messages to be persuasive. In addition, previous speech act research has indicated that although indirectness may be a good signaler of politeness, it may not necessarily enhance the comprehensibility of speech acts (e.g. Bardovi-Harlig and Hartford 1996; Thonus 1999). Comprehensibility was measured by asking participants to indicate whether they thought the e-mail was 'clear', 'well-structured' and 'informative'. The scales were based on a validated questionnaire used in Hoeken (1995). Internal consistency of the scales in the present study was excellent $(\alpha=.93)$.

\subsubsection{Reasonableness of request. As earlier studies (Blum-Kulka and} House 1989; Hendriks 2002) have shown that the required degree of politeness is (partially) determined by context-specific factors such as rights and obligations of interactants and likelihood of compliance, the questionnaire included a measure of (perceived) reasonableness of request. In addition, reasonableness ratings allowed us to check whether the different scripts for the situations could be regarded as comparable. Reasonableness of request was measured by asking participants to give their opinion about three statements: 'It is likely that the person who received this e-mail will comply with this request', 'The writer of this e-mail has the right to make this request' and 'The receiver of this e-mail has the obligation to fulfill this request'. Scales were based on previous research (Blum-Kulka and House 1989; Hendriks 2002). Internal consistency of the scales in the present study was good $(\alpha=.85)$.

\subsection{Results and discussion}

3.2.1. Personality dimensions. The main research question was to what extent variations in syntactic request modification affected participants' 
Table 3. Personality Dimensions of Sender in Function of Modification and Power Distance $(1=$ totally disagree; 7 = totally agree; study $I)$

\begin{tabular}{|c|c|c|c|c|c|c|c|}
\hline & \multicolumn{2}{|c|}{ power } & \multicolumn{2}{|c|}{ agreeableness } & \multicolumn{2}{|c|}{ competence } & \multirow[b]{2}{*}{$n$} \\
\hline & $M$ & $S D$ & $M$ & $S D$ & $M$ & $S D$ & \\
\hline \multicolumn{8}{|l|}{ - modification } \\
\hline High power distance & 3.76 & 1.15 & 4.25 & 1.13 & 4.67 & 1.05 & 55 \\
\hline Low power distance & 4.01 & 1.32 & 4.85 & 1.74 & 5.27 & 1.42 & 55 \\
\hline \multicolumn{8}{|l|}{+ modification } \\
\hline High power distance & 3.84 & 1.19 & 4.10 & 1.44 & 4.57 & 1.39 & 55 \\
\hline Low power distance & 3.88 & 0.97 & 4.96 & 1.02 & 5.27 & 0.91 & 55 \\
\hline
\end{tabular}

evaluation of the sender (Table 3). Two-way ANOVAs with modification and power distance as independent variables showed that modification did not have a significant effect on participants' evaluations of sender's power ( - modification: $M=3.88, S D=1.24 ;+$ modification: $M=$ 3.86, $S D=1.08)$, competence $(-$ modification: $M=4.97, S D=1.28$; + modification: $M=4.92, S D=1.22$ ) or agreeableness (- modification $M=4.55, S D=1.33$; + modification: $M=4.53, S D=1.32$ all $F$ 's $<1$ ). In other words, inclusion of the past tense modal in the request strategy did not affect recipients' judgments about the personality of the writer of the e-mail. The analyses did however reveal that power distance had an effect on participants' evaluations of two personality dimensions: sender's competence $\left(F(1,216)=15.94, p<.001, \eta^{2}=.07\right)$ and sender's agreeableness $\left(F(1,216)=18.35, p<.001, \eta^{2}=.08\right)$. The writer in the low power distance situation was found to be more competent $(M=5.27$, $S D=1.19)$ than the writer in the high power distance situation $(M=4.62, S D=1.23)$. The writer in the low power distance situation was also found to be more agreeable $(M=4.91, S D=1.26)$ than the writer in the high power distance situation $(M=4.17, S D=1.29)$. Interaction between modification and power distance was not significant for any of the personality dimensions (all $F$ 's $<1$ ).

3.2.2. Comprehensiblity. A two-way ANOVA with modification and power distance as independent variables revealed that syntactic modification had no effect on the perceived comprehensibility of the request $(F<1)$, but that power distance $\operatorname{did}(F(1,216)=27.59, p<.001$, $\left.\eta^{2}=.11\right)$. The request in the high power distance situation $(M=4.71$, $S D=1.60)$ was found to be less comprehensible than the request in the low power distance $(M=5.75, S D=1.32)$, regardless of whether the request was formulated with present tense modal 'can' or with past tense 
Table 4. Comprehensibility and Reasonableness in Function of Modification and Power Distance $(1=$ totally disagree; $7=$ totally agree; study I)

\begin{tabular}{lllllll}
\hline & \multicolumn{2}{c}{ comprehensibility } & & \multicolumn{2}{c}{ reasonableness } \\
\cline { 2 - 3 } & $M$ & $S D$ & & $M$ & $S D$ & $n$ \\
\hline $\begin{array}{l}\text { present tense modal } \\
\text { High power distance }\end{array}$ & 4.82 & 1.54 & & 5.07 & 1.29 & 55 \\
$\quad$ Low power distance & 5.75 & 1.46 & 5.50 & 1.21 & 55 \\
past tense modal & & & & & \\
$\quad$ High power distance & 4.60 & 1.66 & & 4.45 & 1.73 & 55 \\
Low power distance & 5.75 & 1.18 & 5.48 & 1.12 & 55 \\
\hline
\end{tabular}

modal 'could' (Table 4). Interaction between modification and power distance was not significant $(F<1)$.

3.2.3. Reasonableness of request. Mean ratings for reasonableness of request were analyzed to check if participants considered the two situations for each role constellation (high / low power distance) as comparable. No significant differences were found between the two requests (A / B) in the high power distance situations $(F<1)$ or between the two requests $(\mathrm{C} / \mathrm{D})$ in the low power distance situations $(F<1)$. The analysis did, however, reveal a significant difference in perceived reasonableness of request $\left(F(1,218)=15.44, p<.001, \eta^{2}=.07\right)$ between the high power distance situations $(M=4.76, S D=1.55)$ and the low power distance situations $(M=5.49, S D=1.16)$. The e-mail request addressed at a status-equal receiver was found to be slightly more reasonable. Interaction between modification and power distance was not significant $(F(1,216)=2.73, p=.10)$.

To summarize, variation in amount of syntactic modification had no effect on the evaluation of the personality of the sender of the request, or on the comprehensibility of the request. This is somewhat surprising, since, on purely theoretical grounds an e-mail request formulated with a past tense modal 'could' can be argued to have a higher politeness value (Brown and Levinson 1987). In fact, earlier empirical studies have demonstrated that in judgment tasks in which participants rank ordered isolated request sequences, 'could you' requests were evaluated as more polite than 'can you' requests (Carrell and Konneker 1981; Clark and Schunk 1980; Tanaka and Kawade 1982). In longer request utterances, such as the e-mail requests in these studies, the differences in politeness value between 'can you' and 'could you' requests may have been too subtle to affect sender evaluation. 
Unexpectedly, power distance affected sender evaluation in that the writer of the e-mail in the high power distance situation was evaluated as less competent and less agreeable, regardless of modification. A possible explanation for this may be that, power distance being an influential factor in determining degree of politeness (e.g. Spencer-Oatey 1997), the manipulation of request modification as operationalized in the present study may have been too subtle to bridge the gap between the politeness levels required for the two different power distance situations. In other words, the high power distance situation, in which the request was addressed at a receiver in a position of authority, may simply have required more elaborate request modification than the inclusion of past tense modal 'could'. Another possible explanation for the effect of power distance may be that, although we took care to script comparable requests for the different power distance situations, the scripting may not have been comparable enough. This explanation would seem to be corroborated by the finding that the request in the high power distance was also evaluated as less comprehensible and less reasonable. A follow-up study with more elaborate request modification and modified scripting was designed to address these concerns.

\section{Study II}

The aim of the follow-up study ${ }^{1}$ reported on here was to examine the effect of more elaborate and varied request modification than the modification included in the first study, where we manipulated the amount of modification rather than the type of modifier. Previous research into speech act formulation has indicated that non-native speakers underuse request modification with regard to amount of modification and also with regard to variety of modifiers. Studies have pointed to the tendency among non-native speakers to use a narrower range of request modifiers and to overuse particular categories of modifier compared to native speakers of English (Blum-Kulka et al. 1989b; Hendriks 2002; Trosborg 1995). In an earlier request production study (Hendriks 2002), Dutch learners of English were found to underuse certain categories of lexical modifiers, such as downtoners (e.g. 'possibly'), understaters (e.g. 'just') and more elaborate lexico-syntactic modifier combinations such as subjectivizers and tense/aspect (e.g. 'I was wondering if ...).

The purpose of the second study was to investigate the effect of more varied types of request modification in e-mail requests on sender evaluation. A study with more elaborate request modification and modified scripts would also allow us to address the concerns raised by our first 
study that the effect of power distance on sender evaluation may have been due to the relatively narrow range of modification in the study or to the scripting of the stimulus material.

\subsection{Method study II}

4.1.1. Participants. Participants were 94 male and 64 female participants. All participants were native speakers of English. The majority of participants were evenly spread among three age categories ranging from 21 to 60 ; all were highly educated.

4.1.2. Material. Two work-related scripts were developed describing an e-mail exchange between a Dutch non-native speaker of English and a native speaker. The situations differed with respect to the power distance between sender and receiver. In the first situation, the sender of the mail made a request to a person in a position of authority, whereas in the second situation, sender and receiver were status equals. The situations were highly similar with respect to the content of the request. As in study I, the e-mails were based on messages written by Dutch non-native speakers of English and contained some typically 'Dutch-English' grammatical structures and lexical/phrasal expressions. The e-mails in the two situations were similar in terms of lay-out and content. In both e-mails, the request was formulated with a conventionally indirect request strategy querying the receiver's ability to comply with the request. The scripts and e-mails are included in appendix C. For both situations, four versions of each e-mail were developed in which the level of politeness was gradually increased by adding either the lexical modifier 'possibly' or the lexicosyntactic combination 'I was wondering if ....' This resulted in the following four request strategies (ordered by increasing level of politeness):

Request 1 (R1): 'Can you ...?' (unmodified ability strategy)

Request 2 (R2): 'Can you possibly ...?' (ability strategy modified with lexical modifier)

Request 3 (R3): 'I was wondering if you could ...' (ability strategy modified with lexico-syntactic modifier + past tense modal)

Request 4 (R4): 'I was wondering if you could possibly ...' (ability strategy modified with lexico-syntactic modifier + past tense modal + lexilexical modifier)

4.1.3. Design and Procedure. The study used a 2 (power distance) $\times 4$ (modification) factorial design. There were two levels of power distance (high vs. low) and four levels of request modification. Each participant 
Table 5. Overview of distribution e-mails and modifiers in questionnaires in study II

\begin{tabular}{lllll}
\hline Version questionnaire & PD & request & PD & request \\
\hline Questionnaire 1 & + & R4 & - & R3 \\
Questionnaire 2 & - & R2 & + & R1 \\
Questionnaire 3 & + & R2 & - & R4 \\
Questionnaire 4 & - & R1 & + & R3 \\
\hline
\end{tabular}

saw two e-mails: one in a high power distance combination and one in a low power distance combination and two of the four possible types of modification (Table 5).

Online questionnaires were constructed and potential participants were invited to take part in the experiment through messages posted on a variety of Internet forums. Participants were randomly assigned to one of the four versions of the questionnaire.

4.1.4. Instrumentation. The instrumentation was the same as in study I, except for the rating scales, which were 5-point Likert scales in study II (see Appendix B).

\subsection{Results and discussion}

4.2.1. Personality dimensions. Of the three sender personality dimensions that participants were asked to evaluate, only evaluations of sender's agreeableness were affected by variations in modification in the e-mail requests (Table 6). A two-way ANOVA with modification and power distance as factors revealed that modification had a significant effect on how participants evaluated the agreeableness of the sender of the e-mail $\left(F(3,306)=3.11, p<.05, \eta^{2}=.03\right)$ and that power distance did not $(F<1)$. Interaction between modification and power distance was not significant for any of the personality dimensions (all $F$ 's $<1$ ). Post-hoc comparisons (Least Significant Difference-LSD) showed that the sender of the e-mails containing the least request modification was evaluated as less agreeable (R1: $M=3.07, S D=1.00$; R2: $M=3.09$, $S D=1.05)$ than the sender of the e-mails containing more elaborate request modification (R3: $M=3.41, S D=1.00 ; \mathrm{R} 4: M=3.46, S D=$ 1.07; all $p$ 's $<.05$ ). This suggests that request modification positively affects sender's likability.

Differences between R1 and R2 or R3 and R4 were not significant (both $p$ 's $>.05$ ), which means inclusion of downtoner 'possibly' did not affect sender evaluation. Variations in request modification did not affect 
Table 6. Personality Dimensions of Sender in Function of Modification and Power Distance $(1=$ totally disagree; $5=$ totally agree; study II)

\begin{tabular}{|c|c|c|c|c|c|c|c|}
\hline & \multicolumn{2}{|c|}{ power } & \multicolumn{2}{|c|}{ agreeableness } & \multicolumn{2}{|c|}{ competence } & \multirow[b]{2}{*}{$n$} \\
\hline & $M$ & $S D$ & $M$ & $S D$ & $M$ & $S D$ & \\
\hline \multicolumn{8}{|l|}{ Request 1 (Can you) } \\
\hline High power distance & 2.79 & 0.77 & 2.97 & 0.92 & 3.48 & 0.93 & 37 \\
\hline Low power distance & 2.81 & 0.97 & 3.17 & 1.08 & 3.15 & 0.91 & 33 \\
\hline \multicolumn{8}{|c|}{ Request 2 (Can you possibly) } \\
\hline High power distance & 2.80 & 1.07 & 3.07 & 1.24 & 3.26 & 0.97 & 44 \\
\hline Low power distance & 2.78 & 0.96 & 3.13 & 0.81 & 3.19 & 0.98 & 38 \\
\hline \multicolumn{8}{|c|}{ Request 3 (I was wondering if) } \\
\hline High power distance & 2.98 & 0.84 & 3.36 & 0.93 & 3.60 & 0.77 & 33 \\
\hline Low power distance & 2.95 & 1.10 & 3.45 & 1.07 & 3.23 & 1.13 & 42 \\
\hline \multicolumn{8}{|c|}{ Request 4 (I was wondering if ... possibly) } \\
\hline High power distance & 2.73 & 1.07 & 3.42 & 0.89 & 3.46 & 0.74 & 43 \\
\hline Low power distance & 2.83 & 1.03 & 3.50 & 1.23 & 3.44 & 0.99 & 44 \\
\hline
\end{tabular}

evaluations of the sender's power (R1: $M=2.80, S D=0.87 ; \mathrm{R} 2$ : $M=2.79, \quad S D=1.02 ; \quad \mathrm{R} 3: \quad M=2.96, \quad S D=0.99, \quad \mathrm{R} 4: \quad M=2.79$, $S D=1.05 ; F<1)$ or sender's competence (R1: $M=3.32, S D=0.93$; R2: $M=3.23, S D=0.97 ; \mathrm{R} 3: M=3.39, S D=1.00 ; \mathrm{R} 4: M=3.45$, $S D=0.87 ; F<1)$.

4.2.2. Comprehensibility. A two-way ANOVA showed that degree of modification in the requests did not have a significant effect on participants' evaluations of the comprehensibility of the requests $(F(3,306)=$ $1.66, p=.176)$ and neither did power distance $(F(1,306)=1.78$, $p=.183$ ). All requests were felt to be reasonably comprehensible (Table 7). Interaction between modification and power distance was not significant $(F(1,306)=2.05, p=.107)$.

4.2.3. Reasonableness. A one-way ANOVA was used to find out whether modification had an influence on how reasonable participants judged the requests to be (Table 7). The analysis revealed that modification did not have a significant effect on perceived reasonableness $(F(3,306)=1.03$, $p=.38)$, but that power distance did $(F(1,306)=5.06, p<.05$, $\left.\eta^{2}=.02\right)$. Interaction between modification and power distance was not significant $(F(1,306)=1.34, p=.261)$. The requests in the e-mails addressed at a status-equal recipient $(M=3.79, S D=1.04)$ were found to be more reasonable than the requests in the e-mail addressed at a recip- 
Table 7. Comprehensibility and Reasonableness in Function of Modification and Power Distance $(1=$ totally disagree; $5=$ totally agree; study II)

\begin{tabular}{|c|c|c|c|c|c|}
\hline & \multicolumn{2}{|c|}{ comprehensibility } & \multicolumn{2}{|c|}{ reasonableness } & \multirow[b]{2}{*}{$n$} \\
\hline & $M$ & $S D$ & $M$ & $S D$ & \\
\hline \multicolumn{6}{|l|}{ Request 1 (Can you) } \\
\hline High power distance & 3.66 & 1.03 & 3.50 & 1.20 & 37 \\
\hline Low power distance & 3.70 & 0.95 & 3.93 & 0.92 & 33 \\
\hline \multicolumn{6}{|c|}{ Request 2 (Can you possibly) } \\
\hline High power distance & 3.33 & 1.22 & 3.26 & 1.10 & 44 \\
\hline Low power distance & 3.46 & 1.06 & 3.81 & 1.02 & 38 \\
\hline \multicolumn{6}{|c|}{ Request 3 (I was wondering if) } \\
\hline High power distance & 3.79 & 1.12 & 3.72 & 0.97 & 33 \\
\hline Low power distance & 3.63 & 1.10 & 3.89 & 0.98 & 42 \\
\hline \multicolumn{6}{|c|}{ Request 4 (I was wondering if ... possibly) } \\
\hline High power distance & 3.40 & 1.03 & 3.62 & 1.04 & 43 \\
\hline Low power distance & 4.04 & 1.06 & 3.56 & 1.19 & 44 \\
\hline
\end{tabular}

ient in a position of authority $(M=3.51, S D=1.09)$, regardless of whether the request included any modifiers.

To summarize, variation in request modification seemed to have little effect on how respondents evaluated the personality of the sender of the e-mail and their ratings of the comprehensibility of the request. Only inclusion of the lexico-syntactic modifier 'I was wondering if ...' positively affected participants' judgments of the sender's agreeableness. Unlike in the first study, power distance had no effect on respondents' evaluations of sender personality or on their comprehensibility ratings. However, in this study, too, respondents evaluated the low power distance request as more reasonable than the high power distance request. This difference did not, however, seem to have affected respondents' evaluations of the sender's personality.

\section{General Discussion}

The purpose of the present study was to examine the effect of request modification in e-mail requests written by Dutch non-native speakers of English on native speakers of English. Since evidence from ILP (written and oral) production studies has indicated that speech act modification might be a potential area of pragmatic failure, the aim of the study was to investigate whether differences in request modification would affect 
judgments of the sender's personality or comprehensibility of requests in non-native-native communication. Findings suggest that the underuse of elaborate request modification in particular, such as the combination of subjectivizer/tense/aspect, may affect perceptions of recipients in that a sender of an e-mail may be regarded as less agreeable by native speakers of English.

As evidence from request production studies has demonstrated that non-native speakers underuse more (linguistically) complex elaborate modification patterns compared to native speakers (Hendriks 2008; Woodfield 2008), findings from the present study suggest that this might indeed be an area of possible pragmatic failure. Underuse of elaborate modification may reflect negatively on a sender's personality and mayin Kasper and Schmidt's terms - result in 'negative stereotyping' by native-speaker message recipients (1996: 156).

Unlike elaborate modification patterns, the use of single modifiers, such as a past tense modal or the downtoner 'possibly', did not affect sender evaluation. Despite the fact that, on purely theoretical grounds, requests modified with a past tense modal or a downtoner can be regarded as more polite than unmodified requests (Brown and Levinson 1987), non-inclusion of these modifiers did not affect sender evaluation negatively. Again, in Kasper and Schmidt's (1996: 156) terms, unmodified requests seem to be regarded as 'perfectly appropriate alternatives'. A possible explanation for this might be that the requests in the e-mails were placed at the end of the message and were preceded by external modifiers, the function of which is to increase the plausibility of a request and to 'set the scene' for the request itself (Blum-Kulka et al. 1989a; Faerch and Kasper 1989). As a consequence, any reduction in politeness level due to undermodification may have been counterbalanced by the use of extensive external modification in the e-mails. Future studies would therefore do well to focus on examining the interplay of external and internal modification to shed light on the contribution of either category of modifier to the overall politeness value and effectiveness of requests.

Another plausible explanation for the absence of marked effects on sender evaluation might be that the e-mails in our study were clearly identifiable as coming from a non-native writer. This may have prompted participants to ignore any 'deviations' from what they may have felt was the 'native norm'. This explanation finds support in the fact that in the online questionnaire some participants commented that they had ignored any unidiomatic or uncharacteristic style elements in the e-mails which they felt were probably due to non-native competence in English. In other words, participants may have judged the senders less harshly because they were non-native speakers. Still, given findings from other studies 
which have shown that non-native speakers can be evaluated negatively for making grammatical errors (Delamere 1996) or on the basis of their non-native accents (Bresnahan et al. 2002; Nejjari et al. forthcoming), this is an area that would need to be addressed in future research.

The focus of the present study has been on pragmatic variation between non-native and native speakers of English, but recent studies in the area of variational pragmatics (e.g. Bella 2009; García 2009; FélixBrasdefer 2009) have demonstrated that pragmatic variation also occurs between and across native varieties of the same language. Consequently, a related area of future research would be to investigate to what extent native speakers of English are evaluated differently as a result of varying degrees of request modification.

Although we had expected power distance to interact with modification in the sense that a higher level of politeness (and hence degree of modification) would be required in the high power distance situation, this effect did not occur in either study. Power distance did have an effect on sender evaluation, regardless of modification, but findings were not consistent across the two studies. In the first study, the sender in the low power distance situation was evaluated as more agreeable and more competent. This effect may have been due to the fact that the situations and requests may not have been comparable enough, since it did not occur in the follow-up study. A possible explanation for the influence of power distance in the first study was that the range of politeness levels might not have been enough to bridge the gap between the politeness levels required in the low and high power distances. This explanation does not seem warranted for the results in the second study, where variations in request modification were more elaborate and should consequently have been enough to bridge the gap.

In both studies, the reasonableness of the requests in the low power distance situation was judged to be higher than for the requests in the high power distance situation. As findings for sender evaluation across the two studies were different however, it is not possible to draw any conclusions about the effect of reasonableness on sender evaluation. As previous research has suggested that context-specific features such as rights and obligations of speaker and hearer may play an important role in determining required levels of politeness for speech acts, future research should also be addressed at examining the influence of situational and contextual variations on determining required politeness levels for requests.

Findings for comprehensibility of the requests were not consistent across the two studies. In the first study, the low power distance request was evaluated as more comprehensible than the high power distance request, whereas in the second study the requests were perceived as equally 
comprehensible. The differences in comprehensibility in the first study may, again, have been due to the fact that the requests were not comparable enough. No evidence was found that increased level of politeness in request strategies may have reduced the comprehensibility of requests. Admittedly, comprehensibility was measured rather indirectly in the present study by asking respondents to indicate whether they thought the e-mails were clear, logically structured and informative, which may be a measure of perceived comprehensibility rather than a measure of actual comprehension. In future research, comprehension could be measured more directly, by, for example, asking respondents to paraphrase messages or interpret requests or by including measures of comprehensibility that have been developed in accentedness studies (e.g., Fayer and Krasinski 1989; Munro et al. 2006).

In the past decade, the rise of internet use and computer-mediated communication has led to an increase in the use of web-based questionnaires, especially since the arrival of more user-friendly software packages (see Wright 2005). In disciplines such as marketing and communication science, online web-based questionnaires are gaining ground, but their use is still relatively uncommon in language research (but see Dewaele 2008; Ping and Sepanski 2006; Roever 2006).

For our study, the most important advantage of an online web-based questionnaire was that it allowed us to gather data efficiently from a wide range of respondents who might otherwise have been difficult to reach, i.e. native speaker respondents from outside the academic community. A possible disadvantage of using online-questionnaires is a selfselection bias. As some individuals are more likely to respond to an invitation to take part in a web-based questionnaire than others, this may lead to systematic bias (see Wright 2005). Although a similar selfselection bias might occur when inviting potential participants to fill in a pen-and-paper questionnaire, it is potentially a more serious disadvantage in a web-based study investigating reactions to non-native English. Respondents taking part in web-based questionnaires are more likely to be frequent internet users and consequently regularly come across different varieties of non-native English on the Internet, which may affect their evaluations of non-native English (positively or negatively). As discussed above, our respondents' comments suggested that they may have judged the non-native writers of the e-mails in our study less harshly. Future research could try to shed more light on the influence of frequent internet use by asking respondents to provide more background information about relevant aspects. Since this study is a first attempt at measuring perception of non-native pragmatic behavior in a quantitative, systematic way, it is difficult to say if our findings might have been different with 
other data collection methods. We would, therefore, welcome future studies using web-based questionnaires and other methods to investigate pragmatic aspects of non-native speakers of English and of other languages.

Finally, the focus of this study has been to investigate non-native-native communication in English. However, given the growth of English as a global language and the concomitant research focus on English as a lingua franca (ELF) (House 2003; Pickering 2006; Seidlhofer 2001, 2004), future research should also be directed at examining the effect of speech act modification on message recipients in non-native-non-native communication. Although research investigating pragmatic aspects of ELF interaction has shown that pragmatic failure in ELF interaction is often resolved through collaborative achievement (Meierkord 2000; Seidlhofer 2004), other studies (House 2000, 2002) have pointed out that mutual agreement in EFL interaction may be based on superficial consensus and that misunderstandings occurring at a deeper level are often overlooked. More research on the role of speech act modification in non-native-nonnative communication could contribute to providing improved insight on pragmatic aspects of ELF interaction.

\section{Acknowledgements}

I would like to thank two anonymous reviewers for their insightful comments on a previous version of this paper.

\section{Note}

1. Study II was carried out in cooperation with Loes van der Broeke as partial fulfillment of her M.A. requirements at Radboud University Nijmegen, the Netherlands.

\section{References}

Bardovi-Harlig, Kathleen and Beverly S. Hartford (1996). Input in an institutional setting. Studies in Second Language Acquisition 18(2): 171-188.

Barron, Anne (2003). Acquisition in interlanguage pragmatics. Learning how to do things with words in a study abroad context. Amsterdam / Philadelphia: Benjamins.

Bayard, Donn, Ann Weatherall, Cynthia Gallois and Jeffery Pittam (2001). Pax Americana? Accent attitudinal evaluations in New Zealand, Australia and America. Journal of Sociolinguistics, 5(1): 22-49.

Bella, Spyridoula (2009). Invitations and politeness in Greek: The age variable. Journal of Politeness Research. Language, Behaviour, Culture 5(2): 243-271. 
Bergman, Marc L. and Gabriele Kasper (1993). Perception and performance in native and non-native apology. In Interlanguage Pragmatics, Gabriele Kasper and Shoshana BlumKulka (eds.), 82-107. New York: Oxford University Press.

Biesenbach-Lucas, Sigrun (2005). Communication topics and strategies in e-mail consultation: comparison between American and international university students. [Electronic Version]. Language Learning and Technology, 9(2):24-46. Retrieved 10 June 2009 from http://lit.msu.edu/vol9num2/biesenbachlucas/.

Biesenbach-Lucas, Sigrun (2007). Students writing emails to faculty: An examination of e-politeness among native and non-native speakers of English [Electronic Version]. Language Learning and Technology 11(2):36-58. Retrieved 10 June 2009 from http:// llt.msu.edu/vol11num2/biesenbachlucas/.

Blankenship, Kevin L. and Thomas Holtgraves (2005). The role of different markers of linguistic powerlessness in persuasion. Journal of Language and Social Psychology 24(1):324.

Blum-Kulka, Shoshana, Brenda Danet and Rimona Gherson (1985). The language of requesting in Israeli society. In Language and social situations, Joseph Forgas (ed.), 114139. New York: Springer.

Blum-Kulka, Shoshana and Juliane House (1989). Cross-cultural and situational variation in requesting behavior. In Cross-cultural pragmatics: Requests and apologies, Shoshana Blum-Kulka, Juliane House and Gabriele Kasper (eds.), 123-154. Norwood, NJ: Ablex.

Blum-Kulka, Shoshana, Juliane House and Gabriele Kasper (1989a). Investigating crosscultural pragmatics: An introductory overview. In Cross-cultural pragmatics: requests and apologies, Shoshana Blum-Kulka, Juliane House and Gabriele Kasper (eds.), 1-36. Norwood, New Jersey: Ablex.

Blum-Kulka, Shoshana, Juliane House and Gabriele Kasper (eds.) (1989b). Cross-cultural pragmatics: Requests and apologies. Norwood, NJ: Ablex.

Bresnahan, Mary Jiang, Rie Ohashi, Reiko Nebashi, Wen Ying Liu and Sachiyo Morinaga Shearman (2002). Attitudinal and affective response toward accented English. Language and Communication 22(2): 171-185.

Brown, Penelope and Stephen Levinson (1987). Politeness: Some universals in language usage. Cambridge: Cambridge University Press.

Burrough-Boenisch, Joy (2005). NS and NNS scientists' amendments of Dutch scientific English and their impact on hedging. English for Specific Purposes 24(1): 25-39.

Byron, Kristin and David C. Baldridge (2007). E-Mail recipients' impressions of senders' likability: The interactive effect of nonverbal cues and recipients' personality. Journal of Business Communication 44(2):137-160.

Carrell, Patricia and Beverly Konneker (1981). Politeness: Comparing native and non-native judgements. Language Learning 31(1): 17-30.

Chang, Yu-Ying and Yi-Ping Hsu (1998). Requests on e-mail: a cross-cultural comparison. RELC Journal 29(2): 121-151.

Clark, Herbert and Dale Schunk (1980). Polite responses to polite requests. Cognition: International Journal of Cognitive Psychology 8(2):111-143.

Delamere, Trish (1996). The importance of interlanguage errors with respect to stereotyping by native speakers in their judgements of second language learners' performance. System 24(3):279-297.

Derwing, Tracey M., Marian J. Rossiter and Maureen Ehrensberger-Dow (2002). "They speaked and wrote real good": Judgements of non-native and native grammar. Language Awareness 11(2):84-99.

DeShields, Oscar W Jr, Gilberto de los Santos, Olivia Aguire Berumen and Celia Cristina Orozco Torres (1997). Salesperson's accent and gender, and consumer purchase inten- 
tions: Implications for Latino salespersons in Mexico and the United States. Journal of International Consumer Marketing 9(3):7-17.

Dewaele, Jean-Marc (2008). 'Appropriateness' in foreign language acquisition and use: Some theoretical, methodological and ethical considerations. International Review of Applied Linguistics in Language Teaching (IRAL) 46(3): 245-265.

Faerch, Claus and Gabriele Kasper (1989). Internal and external modification in interlanguage request realization. In Cross-cultural pragmatics: Requests and apologies, Shoshana Blum-Kulka, Juliane House and Gabriele Kasper (eds.), 221-247. Norwood, NJ: Ablex.

Fayer, Joan M. and Emily Krasinski (1987). Native and non-native judgments of intelligibility and irritation. Language Learning 37(3): 313-326.

Félix-Brasdefer, J. César (2009). Pragmatic variation across Spanish(es): Requesting in Mexican, Costa Rican and Dominican Spanish. Intercultural Pragmatics 6(4): 473515.

García, Carmen (2009). Intra-lingual pragmatic variation in the performance of reprimanding. Intercultural Pragmatics 6(4): 443-472.

Gass, Susan M. and Joyce Neu (eds.) (1996). Speech acts across cultures. Berlin: Mouton de Gruyter.

Gerritsen, Marinel (1995). English advertisements in the Netherlands, Germany, France, Italy and Spain. In Bozena Machová and Slavá Kubátová (eds.), Uniqueness in unity. The significance of cultural identity in European cooperation: 324-341. Prague: Envirostress.

Gerritsen, Marinel, Hubert Korzilius, Frank van Meurs and Inge Gijsbers (2000). English in Dutch commercials: Not understood and not appreciated. Journal of Advertising Research 40(4): $17-31$.

Gerritsen, Marinel and Catherine Nickerson (2004). Fact or fallacy? English as an L2 in the Dutch business context. In Intercultural aspects of specialized communication, Christopher N. Candlin and Maurizio Gotti (eds.), 105-125. Bern: Peter Lang.

Gerritsen, Marinel, Catherine Nickerson, Andreu van Hooft, Frank van Meurs, Ulrike Nederstigt, Marianne Starren and Brigitte Planken (2007). English in product advertisements in Belgium, France, Germany, the Netherlands and Spain. World Englishes 26(3): 291-315.

Groot, Elizabeth de (2006). The genre context of English annual general reports published by Dutch and British corporations. In The Map and the Landscape: Norms and Practices in Genre, Paul Gillaerts and Philip Shaw (eds.), 63-87. Bern: Peter Lang.

Hartford, Beverly S. and Kathleen Bardovi-Harlig (1996). "At your earliest convenience": A study of written student requests to faculty. In Pragmatics and language learning (Vol. 7), Lawrence F. Bouton (ed.), 55-69. Urbana, IL: Division of English as an International Language, University of Illinois, Urbana-Champaign.

Harvey, Robert J., Murry, William D. and Steven E. Markham (1995). A "Big Five" Scoring System for the Myers-Briggs Type Indicator. Paper presented at the 1995 (May) Annual Conference of the Society for Industrial and Organizational Psychology, Orlando. Retrieved on January 5, 2010 from http://harvey.psyc.vt.edu/Documents/BIGFIVE.pdf.

Hemmes, Elly (1994). English language competence: Whose business is it? In Language needs in business, the 18th annual symposium of the international association language and business, Berna Hendriks and Siegfried Wyler (eds.), 213-219. Nijmegen: Nijmegen University Press.

Hendriks, Berna (2002). More on Dutch English ... please? A study of request performance by Dutch native speakers, English native speakers and Dutch learners of English. Nijmegen: Nijmegen University Press.

Hendriks, Berna (2008). Dutch English requests: A study of request performance by Dutch learners of English In Developing Contrastive Pragmatics. Interlanguage and 


\section{Berna Hendriks}

Cross-Cultural Perspectives (Vol. 31), Martin Pütz and JoAnne Neff-van Aertselaer (eds.), 331-350. Berlin: Mouton de Gruyter.

Hoeken, Hans (1995). The design of persuasive texts: effects of content, structure, and style on attitude formation. Enschede: Copyprint 2000.

Hofstede, Geert (2001). Culture's consequences: Comparing values, behaviors, institutions, and organizations across nations (2nd ed.). Thousand Oaks, CA: Sage.

Hosman, Lawrence A. and Susan A. Siltanen (2006). Powerful and powerless language forms: Their consequences for impression formation, Attributions of control of self and control of others, cognitive responses, and message memory. Journal of Language and Social Psychology 25(1). 33-46.

House, Juliane (2000). Understanding misunderstanding: A pragmatic-discourse approach to analysing mismanaged rapport in talk across cultures. In Helen Spencer-Oatey (ed.), Culturally speaking. Managing rapport through talk across cultures, 145-164. London / New York: Continuum.

House, Juliane (2002). Pragmatic competence in lingua franca English. In Lingua franca communication, Karlfried Knapp and Christiane Meierkord (eds.), 245-267. Frankfurt: Peter Lang.

House, Juliane (2003). English as a lingua franca: A threat to multilingualism? Journal of Sociolinguistics 7(4). 556-578.

House, Juliane and Gabriele Kasper (1987). Interlanguage pragmatics: Requesting in a foreign language. In Perspectives on language in performance, Wolfgang Lörscher and Rainer Schulze (eds.), 1250-1288. Tübingen: Narr.

Jung, Ji-Young.(2002). Issues in acquisitional pragmatics. Columbia University Working Papers in TESOL and Applied Linguistics 2(3). 1-34. Retrieved 12 June 2009 from http://journals.tc-library.org/index.php/tesol/article/view/21.

Kasper, Gabriele and Richard Schmidt (1996). Developmental issues in interlanguage pragmatics. Studies in Second Language Acquisition 18(2). 149-169.

Korzilius, Hubert, Frank van Meurs and José Hermans (2006). The use of English in job advertisements in a Dutch national newspaper: on what factors does it depend? In Rogier Crijns and Christiaan Burgers (eds.), Werbestrategien in Theorie und Praxis: Sprachliche Aspekte von deutschen und niederländischen Unternehmensdarstellungen und Werbekampagnen, 147-174. Tostedt: Attikon Verlag.

Leech, Geoffrey (1983). The principles of pragmatics. London: Longman.

Lindemann, Stephanie (2002). Listening with an attitude: A model of native-speaker comprehension of non-native speakers in the United States. Language in Society 31(3). 419441.

Lindemann, Stephanie (2003). Koreans, Chinese or Indians? Attitudes and ideologies about non-native English speakers in the United States. Journal of Sociolinguistics 7(3). 348-364.

Maier, P. (1992). Politeness strategies in business letters by native and non-native English speakers. English for Specific Purposes 11(3). 189-205.

Meierkord, Christiane (2000). Interpreting successful lingua franca interaction. An analysis of non-native / non-native small talk conversations in English [Electronic Version]. Linguistik online 5(1). Retrieved 12 June 2008 from http://www.linguistik-online.de/1_00/ MEIERKOR.HTM.

Meurs, Frank van, Hubert Korzilius and Adriënne Den Hollander (2006a). The persuasive effect of the use of English in external business communication on non-native speakers of English: An experimental case study of the impact of the use of English on a Dutch job site. In Intercultural and international Business Communication. Theory, research and teaching (Vol. 38), Juan Carlos Palmer-Silveira, Miquel F. Ruiz-Garrido and Inmaculada Fortanet-Gómez (eds.), 139-179. Bern: Peter Lang. 
Meurs, Frank van, Hubert Korzilius and Adriënne Den Hollander (2006b). The use of English in job advertisements on the Dutch site Monsterboard.nl and on which factors it depends. ESP Across Cultures, 3. 103-123.

Munro, Murray. J., Derwing, Tracey. M., and Morton, Susan. L. (2006). The mutual intelligibility of L2 speech. Studies in Second Language Acquisition, 28(1). 111-131.

Nejjari, Warda, Marinel Gerritsen, Monique van der Haagen and Hubert Korzilius. forthcoming. Responses to Dutch-accented English.

Nickerson, Catherine C. (2000). Playing the corporate language game: An investigation of the genres and discourse strategies in English used by Dutch writers working in multinational corporations. Amsterdam: Rodopi.

Nunnally, Jum C. and Ira H. Bernstein (1994). Psychometric theory (3rd ed.). New York: McGraw-Hill.

Olshtain, Elite (1989). Apologies across languages. In Cross-cultural pragmatics: requests and apologies, Shoshana Blum-Kulka, Juliane House and Gabriele Kasper (eds.), 155-173. Norwood, NJ: Ablex.

Olshtain, Elite and Liora Weinbach (1993). Interlanguage features of the speech act of complaining. In Interlanguage Pragmatics, Gabriele Kasper and Shoshana Blum-Kulka (eds.), 108-122. New York: Oxford University Press.

Onna, Bert van and Carel Jansen (2006). How multilingual are the Dutch really? On proficiency in Dutch, English, French, and German in Dutch organizations. Belgian Journal of English Language and Literatures, New Series 4. 169-180.

Pair, Rob le (2005). Politeness in the Netherlands: indirect requests. In Leo Hickey and Miranda Stewart (eds.), Politeness in Europe 66-81. Clevedon: Multilingual Matters.

Pickering, Lucy (2006). Current research on intelligibility in English as a lingua franca. Annual Review of Applied Linguistics 26. 219-233.

Ping Li and Sara Sepanski (2006). Language history questionnaire: A Web-based interface for bilingual research. Behavior Research Methods 38(2). 202-211.

Planken, Brigitte (2005). Managing rapport in lingua franca sales negotiations: A comparison of professional and aspiring negotiators. English for Specific Purposes 24 (4). $381-400$.

Roever, Carsten (2006). Validation of a web-based test of ESL pragmalinguistics. Language Testing, 23(2). 229-256.

Schwartz, Shalom. H. (1994). Are there universal aspects in the structure and contents of human values? Journal of Social Issues, 50(4), 19-45.

Seidlhofer, Barbara (2001). Closing a conceptual gap: the case for a description of English as a lingua franca. International Journal of Applied Linguistics 11(2). 133-158.

Seidlhofer, Barbara (2004). Research perspectives on teaching English as a lingua franca. Annual Review of Applied Linguistics 24. 209-239.

Seidlhofer, Barbara, Angelika Breiteneder and Marie-Luise Pitzl (2006). English as a lingua franca in Europe: challenges for applied linguistics. Annual Review of Applied Linguistics 26. 3-34.

Sherman, Richard C. (2003). The mind's eye in cyberspace: Online perceptions of self and others. In Towards cyberpsychology: Mind, cognitions and society in the internet age, Giuseppe Riva and Carlo Galimberti (eds.), 54-71. Amsterdam: IOS Press.

Spencer-Oatey, Helen (1997). Unequal relationships in high and low power distance societies. A comparative study of tutor-student role relations in Britain and China. Journal of Cross-Cultural Psychology 28(3). 284-302.

Tanaka, Shigenori and Saiki Kawade (1982). Politeness strategies and second language acquisition. Studies in Second Language Acquisition 5(1). 18-33.

Thomas, Jenny (1983). Cross-cultural pragmatic failure. Applied Linguistics, 4(2). 91-112. 
Thonus, Terese (1999). How to communicate politely and be a tutor, too: NS-NNS interaction and writing center practice. Text 19. 253-279.

Trosborg, Anna (1987). Apology Strategies in natives/non-natives. Journal of Pragmatics 11(1). $147-167$.

Trosborg, Anna (1995). Interlanguage pragmatics: Requests, complaints and apologies. Berlin: Mouton de Gruyter.

Tsalikis, John, Oscar W Jr DeShields and Michael S LaTour (1991). The role of accent on the credibility and effectiveness of the salesperson. Journal of Personal Selling and Sales Management 11(1). 31-41.

Wijst, P. van der (1996). Politeness in requests and negotiations. Dordrecht: ICG Printing.

Woodfield, Helen (2008). Interlanguage requests: A contrastive study. In Developing Contrastive Pragmatics. Interlanguage and Cross-Cultural Perspectives (Vol. 31), Martin Pütz and JoAnne Neff-van Aertselaer (eds.), 231-264. Berlin: Mouton de Gruyter.

Wright, K. B. (2005). Researching Internet-based populations: Advantages and disadvantages of online survey research, online questionnaire authoring software packages, and web survey services. Journal of Computer-Mediated Communication, 10(3), article 11. http://jcmc.indiana.edu/vol10/issue3/wright.html (accessed 5 January 2010).

Yun, Gi W. and Trumbo, Craig, W. (2000). Comparative response to a survey executed by post, e-mail, and web form. Journal of Computer-Mediated Communication 6(1). Retrieved 5 January 2010 from http://jcmc.indiana.edu/vol6/issuel/yun.html

\section{Appendix A}

Scripts and emails for study I

High power distance situation: A

Imagine the following situation:

You are Steven Murray and you work in London as head of the international communications division of the multinational Alpha. Your department is responsible for the supervision of the trainees at all of Alpha's European divisions. You have e-mail contact with these trainees on a regular basis. You have just received an e-mail from Bram Driessen, a trainee at the Dutch division of Alpha in Eindhoven. Bram works for the marketing department in Eindhoven.

This is the e-mail:

Date: Mon, 6 Nov, 2006 09:15:10

From: B.Driessen@alpha.com

To: S.Murray@alpha.com

Subject: Check the text-advertisement

Dear Mr. Murray, As you probably know, at the moment I am writing several texts for advertisements of our new product-line, which will be launched in March. 
Currently I am working on an advertisement-text for the international magazine 'Marketing Magazine'. This advertisement will appear in the coming issue of the magazine. I hereby send you two text-examples for the advertisement. The final advertisement-text has to be send to the editors of Marketing Magazine at the end of next week. [Can or Could] you read the texts in the attachment and add some comments? Thanks in advance.

With kind regards, Bram Driessen

Trainee, Marketing Department Alpha Holland

High power distance situation: B

Imagine the following situation:

You are Simon Swinborn, head of the marketing department at the main office of the multinational corporation CBA in London. Your department is responsible for, among other things, coordinating and fine-tuning the marketing plans for the various European CBA business units. You keep in touch with colleagues from these establishments on a regular basis. You have just received an e-mail from Hans Gelder, who works for the marketing department in Amsterdam. Hans and his colleagues are preparing the corporate objectives for their department.

This is the e-mail:

Date: Wed, 22 Nov 2006 09:40:12

From: H.Gelder@cba.com

To: S.Swinborn@cba.com

Subject: Corporate objectives

Dear Mr. Swinborn,

For our marketing department in Amsterdam, we are currently formulating the corporate objectives for 2007. In order to do this, we not only want to involve the 2006 corporate objectives evaluation results, but also the recently formulated general objectives by the head office. It came to our attention that some things have been changed compared to the last couple of years. Our plan is to finish drafting these objectives for 2007 before the beginning of the new year. [Can or Could] you read the attached file with the corporate objectives and let me know if they fit the head office's new policy? Thanks in advance.

Kind regards,

Hans Gelder

Marketing employee CBA Amsterdam 
Low power distance situation: $\mathrm{C}$

Imagine the following situation:

You are Brian Taylor and you are a product design manager at Design Works, an international company in London. Communication between the European business units of Design Works is open and frequent, with regular e-mail contact between colleagues. You have just received an e-mail from Herman de Jong, one of the marketing managers of the Amsterdam business unit. Herman is responsible for the marketing communication surrounding new product launches.

This is the e-mail:

Date: Wed, 22 Nov 2006 09:40:12

From: h.dejong@designworks.com

To: b.taylor@designworks.com

Subject: Product specifications

Dear Brian,

As you might know, I am responsible for the marketing of the launch of our new product, PLX3, on the European market. The marketing campaign for the PLX3 starts in 2 months. At this moment I am checking the PLX3 product specifications. With this e-mail I am sending you a list with the product specifications as included in the campaign. [Can or Could] you read through the list and send me the necessary corrections? Thank you in advance!

Yours sincerely,

Herman de Jong

Design Works, Marketing division

Low power distance situation: $\mathrm{D}$

Imagine the following situation:

You are Matthew Willis and you are a manager in the financial department of the UK business unit of a large multinational, Delta-Management. You have a good working relationship with your international colleagues from the Delta-Management business units all over the world. You have regular e-mail contact with these colleagues. You have just received an e-mail from Jaap de Groot, who is a communications manager at the Dutch Delta-Management business unit in Amsterdam. Jaap is responsible for the Delta-Management website. 
This is the e-mail:

Date: Wed, 22 Nov 2006 09:40:12

From: J.deGroot@deltaman.com

To: M.Willis@deltaman.com

Subject: Check information

Dear Matthew,

As you might know, I am responsible for the website of Delta-Management. At the moment the website is undergoing a total revision and on the new website we would like to add a new page with financial information about the Delta-Management department in London. The page is about to be finished, but we would like to be sure that all the information on it is correct and that there is no wrong information on the website. [Can or Could] you check this webpage (see attachment) and mail possible corrections and additions to me? Thank you in advance!

Kind regards,

Jaap de Groot,

Delta-Management, Communications department

\section{Appendix B}

Questionnaire

Radboud University Nijmegen

Business Communication Studies

Dear participant,

We would like to invite you to participate in a web survey about digital communication for the Radboud University Nijmegen, the Netherlands.

The survey will take about 5 minutes of your time. We would very much appreciate your help.

Please fill in the access code in the box below to start the survey.

Access code:

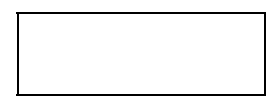

If you have any questions about this survey, please contact:

Dr. Berna Hendriks

Department of Business Communication

Radboud University Nijmegen, the Netherlands 
b.hendriks@let.ru.nl

Radboud University Nijmegen, the Netherlands

Business Communication Studies

\section{Instructions}

In this survey you will be asked to give your opinion about two e-mail messages. As we are interested in your spontaneous reactions to the messages, we would like to ask you not to think too long about your answers. We are interested in your personal opinion, so your answers can never be wrong. For both e-mail messages you will first be asked to read a description of the situation in which the e-mail was sent, followed by the e-mail itself. You will then be asked to give your opinion about the e-mail using the following type of scale:

Example:

I think this email is:

Organized totally disagree $\begin{array}{lllllllllll} & \bigcirc & \bigcirc & \bigcirc & \bigcirc & \bigcirc & \bigcirc & \bigcirc \\ 1 & 2 & 3 & 4 & 5 & 6 & 7\end{array}$

You are asked to check the circle that best represents your opinion. For example, if you totally disagree with the statement 'this e-mail is organized', you check circle (1). If you totally agree with the statement, check circle (7). If you neither agree nor disagree with the statement, check circle (4), etc.

Please do not leave the page until you have answered all questions, as this will clear all your answers.

Please do not press the 'ENTER' or 'RETURN' key while you are answering the questions, as this will terminate the program.

Click here to start with the first e-mail.

Situation 1

Imagine the following situation:

You are Steven Murray and you work in London as head of the international communications division of the multinational Alpha. Your department is responsible for the supervision of the trainees at all of Alpha's European divisions. You have e-mail contact with these trainees on a regular basis. You have just received an e-mail from Bram Driessen, a trainee at the Dutch division of Alpha in Eindhoven. Bram works for the marketing department in Eindhoven. 
This is the e-mail:

Date: Mon, 6 Nov, 2006 09:15:10

From: B.Driessen@alpha.com

To: S.Murray@alpha.com

Subject: Check the text-advertisement

Dear Mr. Murray

As you probably know, at the moment I am writing several texts for advertisements of our new product-line, which will be launched in March. Currently I am working on an advertisement-text for the international magazine 'Marketing Magazine'. This advertisement will appear in the coming issue of the magazine. I hereby send you two text-examples for the advertisement. The final advertisement-text has to be send to the editors of Marketing Magazine at the end of next week. [Can or Could] you read the texts in the attachment and add some comments? Thanks in advance.

With kind regards,

Bram Driessen

Trainee, Marketing Department Alpha Holland

For each of the scales below, please check the circle which best represents your opinion:

It is likely that the person who received this e-mail will comply with this request.

totally disagree $\bigcirc \bigcirc \bigcirc \bigcirc \bigcirc \bigcirc$ totally agree

The writer of this e-mail has the right to make this request.

totally disagree $\bigcirc \bigcirc \bigcirc \bigcirc \bigcirc \bigcirc \bigcirc$ totally agree

The receiver of this e-mail has the obligation to fulfill this request.

totally disagree $\bigcirc \bigcirc \bigcirc \bigcirc \bigcirc \bigcirc \bigcirc$ totally agree

I think this e-mail is:

clear totally disagree $\bigcirc \bigcirc \bigcirc \bigcirc \bigcirc \bigcirc \bigcirc$ totally agree well-structured totally disagree $\bigcirc \bigcirc \bigcirc \bigcirc \bigcirc \bigcirc \bigcirc$ totally agree informative totally disagree $\bigcirc \bigcirc \bigcirc \bigcirc \bigcirc \bigcirc \bigcirc$ totally agree

I think the person who wrote this e-mail is:

reliable totally disagree $\bigcirc \bigcirc \bigcirc \bigcirc \bigcirc \bigcirc \bigcirc$ totally agree sympathetic totally disagree $\bigcirc \bigcirc \bigcirc \bigcirc \bigcirc \bigcirc \bigcirc$ totally agree 


$\begin{array}{lllll}\text { authoritative } & \text { totally disagree } & 0 & 0 \bigcirc \bigcirc \bigcirc \bigcirc & \text { totally agree } \\ \text { competent } & \text { totally disagree } & \bigcirc \bigcirc \bigcirc \bigcirc \bigcirc \bigcirc \bigcirc & \text { totally agree } \\ \text { considerate } & \text { totally disagree } & \bigcirc \bigcirc \bigcirc \bigcirc \bigcirc \bigcirc \bigcirc & \text { totally agree } \\ \text { intelligent } & \text { totally disagree } & \bigcirc \bigcirc \bigcirc \bigcirc \bigcirc \bigcirc \bigcirc & \text { totally agree } \\ \text { controlling } & \text { totally disagree } & \bigcirc \bigcirc \bigcirc \bigcirc \bigcirc \bigcirc & \text { totally agree } \\ \text { tactful } & \text { totally disagree } & \bigcirc \bigcirc \bigcirc \bigcirc \bigcirc \bigcirc \bigcirc & \text { totally agree } \\ \text { dominant } & \text { totally disagree } & \bigcirc \bigcirc \bigcirc \bigcirc \bigcirc \bigcirc \bigcirc & \text { totally agree }\end{array}$

We would welcome any comments that you might have about the e-mail you have just read:

Click here for situation 2

Situation 2

Imagine the following situation:

You are Matthew Willis and you are a manager in the financial department of the UK business unit of a large multinational, Delta-Management. You have a good working relationship with your international colleagues from the Delta-Management business units all over the world. You have regular e-mail contact with these colleagues. You have just received an e-mail from Jaap de Groot, who is a communications manager at the Dutch Delta-Management business unit in Amsterdam. Jaap is responsible for the Delta-Management website.

This is the e-mail:

Date: Wed, 22 Nov 2006 09:40:12

From: J.deGroot@deltaman.com

To: M.Willis@deltaman.com

Subject: Check information

Dear Matthew,

As you might know, I am responsible for the website of Delta-Management. At the moment the website is undergoing a total revision and on the new website we would like to add a new page with financial informa- 
tion about the Delta-Management department in London. The page is about to be finished, but we would like to be sure that all the information on it is correct and that there is no wrong information on the website. [Can or Could] you check this webpage (see attachment) and mail possible corrections and additions to me? Thank you in advance!

Kind regards, Jaap de Groot, Delta-Management, Communications department

For each of the scales below, please check the circle which best represents your opinion:

It is likely that the person who received this e-mail will comply with this request.

$$
\text { totally disagree } \bigcirc \bigcirc \bigcirc \bigcirc \bigcirc \bigcirc \bigcirc \text { totally agree }
$$

The writer of this e-mail has the right to make this request.

$$
\text { totally disagree } \bigcirc \bigcirc \bigcirc \bigcirc \bigcirc \bigcirc \bigcirc \text { totally agree }
$$

The receiver of this e-mail has the obligation to fulfill this request.

totally disagree $\bigcirc \bigcirc \bigcirc \bigcirc \bigcirc \bigcirc \bigcirc$ totally agree

I think this e-mail is:

$\begin{array}{llll}\text { clear } & \text { totally disagree } & \bigcirc \bigcirc \bigcirc \bigcirc \bigcirc \bigcirc \bigcirc & \text { totally agree } \\ \text { well-structured } & \text { totally disagree } & 0 \bigcirc \bigcirc \bigcirc \bigcirc \bigcirc \bigcirc & \text { totally agree } \\ \text { informative } & \text { totally disagree } & \bigcirc \bigcirc \bigcirc \bigcirc \bigcirc \bigcirc \bigcirc & \text { totally agree }\end{array}$

\begin{tabular}{|c|c|c|c|}
\hline reliable & totally disagree & $0 \bigcirc 00 \bigcirc \bigcirc 0$ & totally agree \\
\hline sympathetic & totally disagree & $\bigcirc \bigcirc \bigcirc \bigcirc \bigcirc \bigcirc \bigcirc$ & totally agree \\
\hline authoritative & totally disagree & $\bigcirc \bigcirc \bigcirc \bigcirc \bigcirc \bigcirc \bigcirc$ & totally agree \\
\hline competent & totally disagree & $\bigcirc \bigcirc \bigcirc \bigcirc \bigcirc$ & totally agr \\
\hline considerate & totally disagree & & totally ag \\
\hline intelligent & totally disagree & $\bigcirc \bigcirc \bigcirc \bigcirc \bigcirc c$ & totally ag \\
\hline controlling & totally disagree & $\bigcirc \bigcirc \bigcirc$ & totally a \\
\hline tactful & totally disagree & & totally ag \\
\hline ominant & totally disagree & $u$ & totally ag \\
\hline
\end{tabular}

I think the person who wrote this e-mail is: 
We would welcome any comments that you might have about the e-mail you have just read:

\section{Appendix C}

Scripts for Study II; High power distance

Imagine the following situation:

You are Alex Daniels, head of the ICT department of a multinational company in London. As head of this department, you are the supervisor of several project groups, Research and Development being one of them. The past six months, this group has worked on the development of the company's Intranet. You have just received an email message from Peter Jansen, one of the Dutch researchers on the project group. He has worked in the project group for several years.

This is the e-mail:

Date: Tue, 8 Nov Oct 2005 09:20:46+0100

From: p.jansen@booksworth.com

To: a.daniels@booksworth.com

Subject: Launch intranet

Dear Alex,

As you know, our project group has been working on the development of the company's Intranet. Before it can be launched, several applications have to be tested by the Implementation Group. We have written a report in which the complete process from development to implementation is described. A summary is included as well that describes the different steps that need to be taken before the launch of the Intranet. After your approval of this summary, the report can be sent to the Implementation Project Group who will then launch the Intranet. [Can you read the summary today $]^{*}$ so I can send the report to the Implementation Project Group tomorrow? Hopefully, you can find the time to do this for me.

Thank you in advance.

Peter

* Head Act of request; in the other 3 versions the requests were:

- Can you possibly read the summary today

- I was wondering if you could read the summary today

- I was wondering if you could possibly read the summary today 


\section{Appendix D}

Scripts for Study II; low power distance

Imagine the following situation:

You are Lesley Kings, a PR manager at a multinational company in London. You have just received an email from your Dutch colleague Jan de Vries, who is a PR manager at the company's head office in Amsterdam. The PR department at the head office is responsible for the internal communication of your company. In the past you have organized several PR events with Jan, and got to know each other fairly well.

This is the e-mail:

Date: Tue, 8 Nov Oct 2005 09:20:46 +0100

From: j.devries@booksworth.com

To: 1.kings@booksworth.com

Subject: Anniversary company magazine

Dear Lesley,

As you know, our company magazine has its 10th anniversary this year and publishes special editions. The next edition, which will be printed tomorrow, will highlight the PR department, with your department in London in particular. The copywriter has sent me a few pages about your recent projects and about the people working at your department. I am not sure though, if all the information is up to date and whether you might have some additional information. After your approval of the story, it can be sent to the publishing department. [Can you read the story today]* so it can be added to this month's edition? Hopefully, you can find the time to do this for me.

Thank you in advance.

Jan

* In the other 3 versions the requests were:

- Can you possibly read the story today

- I was wondering if you could read the story today

- I was wondering if you could possibly read the story today 